COCRYSTAL: NICOTINAMIDE AS THE COFORMER

\author{
Hairunnisa ${ }^{1,2}$, Iyan Sopyan ${ }^{1}$, Dolih Gozali ${ }^{1}$ \\ ${ }^{1}$ Departemen Farmasetika dan Teknologi Farmasi, Fakultas Farmasi Universitas \\ Padjadjaran, Jatinangor, Jawa Barat, Indonesia, 45363 \\ ${ }^{2}$ Akademi Farmasi YARSI, Pontianak Timur, Kalimantan Barat, Indonesia, 78232
}

Corresponding author: Hairunnisa (hairunnisa18001@mail.unpad.ac.id)

| Received: 26 Mei 2019

\begin{tabular}{l}
\hline ARTICLE HISTORY \\
$\mid$ Revised: 16 Juni 2019
\end{tabular}

\begin{abstract}
Cocrystal is one of alternative ways to improve drug solubility in the water and thus increase its poor bioavailability. There are various method in cocrystallization, i.e. hot melt extrusion, solvent evaporation, solvent drop grinding, and slurry. Nicotinamide has been widely used as a coformer due to its chemical structure thus it has a great opportunity to cocrystallize with various active pharmaceutical ingredients. Generally, cocrystal of the drugs resulted an increase in its dissolution rate rather than its pure form dissolution rate.
\end{abstract}

Key words: cocrystal, nicotinamide, dissolution

\title{
KO-KRISTAL: NIKOTINAMID SEBAGAI KOFORMER
}

\begin{abstract}
Abstrak
Kokristal merupakan cara alternatif yang dapat dilakukan untuk meningkatkan kemampuan melarut obat yang sukar larut dalam air dan meningkatkan bioavailabilitas obat yang buruk. Ada berbagai teknik yang dapat dilakukan dalam pembuatan kokristal seperti Hot Melt Extrusion, solvent evaporation, solvent drop grinding, slurry. Nikotinamid telah banyak digunakan sebagai koformer dalam pembentukan ko-kristal. Berdasarkan struktur kimianya, nikotinamid memiliki peluang besar untuk membentuk ko-kristal dengan berbagai macam bahan aktif farmasi. Modifikasi kokristal bahan aktif farmasi juga dapat maningkatkan laju disolusi dari bahan aktif farmasi itu sendiri dibandingkan kecepatan disolusi bahan aktif farmasi murninya
\end{abstract}

Kata kunci: kokristal, nikotinamid, disolusi

\section{Pendahuluan}

Pengembangan Bahan Aktif Farmasi (BAF) saat ini terus menerus dilakukan untuk mendapatkan suatu zat dengan sifat fisikokimia yang baik, terutama kelarutan. Dimana kelarutan suatu zat akan berpengaruh terhadap bioavailabilitas dari zat tersebut dan juga akan mempengaruhi efek farmakologinya. Dalam industri farmasi, 
sifat biofarmasetikal seperti disolusi dan kelarutan yang buruk dari suatu zat aktif merupakan masalah utama. Obat yang kelarutannya buruk dalam tubuh akan terbuang secara percuma dan menurunkan efikasi obat itu sendiri (1). Perbaikan terhadap sifat fisik Bahan Farmasi Aktif (BAF) perlu dilakukan dengan berbagai macam pendekatan, banyak pendekatan yang bisa dilakukan untuk memperbaiki hal tersebut, salah satunya dengan pendekatan kokristal. Kokristal merupakan cara alternatif yang dapat dilakukan untuk meningkatkan kemampuan melarut obat yang sukar larut dalam air dan meningkatkan bioavailabilitas obat yang buruk. Meskipun, definisi "cocrystal farmasi" masih diperdebatkan, pendekatan ini sangat berguna, dan penting untuk pembentukan Kristal baru dari Bahan Aktif Farmasi (BAF). Kokristal dapat diterapkan dalam industri farmasi untuk peningkatan sifat fisikokimianya seperti laju disolusi, titik leleh, kelarutan, stabilitas kimia, dan lain-lain $(2,3)$.

Ko-kristalisasi adalah teknik rekayasa kristal yang muncul dan digunakan untuk memodifikasi sifat Bahan Aktif Farmasi (BAF). Ini mungkin karena kokristalisasi merupakan pengembangan baru bentuk padat dengan struktur yang berbeda dari molekul penyusunnya (1). Kokristal dapat didefinisikan sebagai kompleks dari dua senyawa atau lebih yang saling terikat dalam suatu kisi kristal melalui ikatan nonkovalen biasanya ikatan hidrogen. Saat ini kokristal menjadi alternatif yang terus di kembangkan sebagai sediaan padat farmasi. Kokristal dapat terbentuk antara suatu zat aktif obat dengan koformer yang memiliki ikatan hidrogen dengan zat aktif tersebut untuk membentuk sebuah kristal baru (4). Ada berbagai teknik yang dapat dilakukan dalam pembuatan kokristal seperti Hot Melt Extrusion (5), solvent evaporation (6), solvent drop grinding (7), slurry (8). Pembentukan kokristal ini diharapkan dapat dimanfaatkan untuk meningkatkan keuntungan dari bahan aktif farmasi secara signifikan. Teknologi kokristalisasi ini dapat digunakan untuk desain obat baru dengan keuntungannya yang ramah lingkungan serta kelarutan dan bioavailabilitas yang beberapa kali lipat lebih tinggi daripada senyawa obat tersebut jika dibuat dengan teknologi lainnya (9). Nikotinamida (vitamin B3) digunakan sebagai pembentuk kokristal (cocrystal former) yang bersifat inert, dan mempunyai toksisitas yang rendah (10). Sebagai koformer, Atom Nitrogen pada kelompok pirimidin dapat membentuk Heteresinton dengan Bahan Aktif Farmasi (11).

\section{Metode}

Review ini dibuat berdsarkan literatur yang diperoleh dari database Scopus dan Google Scholar menggunakan kata kunci spesifik "Co-Crystals, methods and Nicotinamide". Mengikuti kriteria inklusi (artikel dan review) dan eksklusi (opini dan materi yang tidak sesuai dengan topik bahasan)

\section{Definisi Kokristal}

Kokristal didefinisikan sebagai komponen kristal yang terdiri dari dua atau lebih komponen padat dalam rasio stoikiometrik yang sesuai interaksi non-kovalen. Kokristal menjadi perhatian di industri farmasi karena berpotensi untuk menyesuaikan sifat fisiokimia dan biologis bahan aktif farmasi, seperti titik leleh, kelarutan, bioavilabilitas dan stabilitas kimia. Interaksi antar molekul pada sintesis kokristal didesain melalui penggunaan sintesis supermolekul, seperti pada pasangan asam karboksilat / asam karboksilat, asam karboksilat / nitrogen aromatik, asam karboksilat / amida dan amida / nitrogen aromatik. (12)

Kokristal disatukan oleh sintesis supramolecular. Untuk dapat membentuk kokristal Bahan aktif farmasi dan koformer yang dipilih harus mampu membentuk 
heterosinton atau homosinton. Ada beberapa langkah yang harus dipertimbangkan dalam pendekatan sintesis supramolekul, yaitu pemilihan molekul target sebagai zat aktif yang akan dibuat kokristal, Menemukan koformer yang memiliki gugus fungsi yang mampu membentuk ikatan hidrogen dengan zat aktif, dan Memilih metode yang sesuai dan efektif dalam pembentukan kokristal. Pendekatan alternatif lain untuk penemuan bentuk kristal adalah sintesis supramolekul sebagai alat desain yang lebih selektif sehingga dapat menghemat waktu dan biaya, memprediksi adanya ikatan hidrogen yang terjadi antara zat aktif dan koformer. Sebuah synthon di Kokristal adalah interaksi non-kovalen yang melibatkan ikatan hidrogen, Van der Waals, dan elektron $\pi-\pi$. Interaksi supra molekul sinton dapat diprediksi oleh metode in silico, hal ini dilakukan untuk melihat interaksi yang terjadi antara Bahan Aktif Farmasi dengan Koformer yang digunakan dalam pembuatan kokristal. Terutama untuk melihat ikatan hidrogen yang terbentuk (6). Kokristal yang terbentuk dapat diformulasikan menjadi bentuk sediaan yang diharapkan memiliki kelarutan dan disolusi yang lebih baik.

\section{Metode Pembuatan}

\section{Hot Melt Extrusion}

Teknologi HME dapat digunakan untuk menghasilkan kokristal, biasanya digunakan pada skala pabrik dengan mengendalikan suhu dan deformasi geser. Salah satu keunggulan HME prosesnya tidak memerlukan pelarut, pengerjaannya hanya dalam langkah tunggal, dan proses pengerjaannya mudah diskalakan, teknologi HME berkembang pesat di bidang farmasi dengan Parameter yang perlu diperhatikan dalam HME, yaitu, suhu, kecepatan putara sekrup, dan feed rate, memiliki efek signifikan pada output kristal kristal. Pengaturan suhu di atas titik leleh eutektik merupakan persyaratan untuk pembentukan kokristal (5). Ekstrusi juga merupakan metode yang berguna untuk sintesis kokristal, pencampuran yang terjadi sangat efisien dan kontak permukaan antar zat lebih baik, pembentukan kokristal tanpa menggunakan pelarut. Pemilihan Metode ini terutama tergantung pada stabilitas termodinamika senyawa (13).

\section{Solvent Evaporation}

Sintesis kokristal berdasarkan metode solvent evaporation mungkin lebih efektif dan efisien untuk penyempurnaan pembentukan kokristal; selanjutnya, metode ini biasa digunakan dalam industri farmasi (14). Metode Solvent Evaporation secara luas digunakan dalam pembuatan kokristal di bidang farmasi (14), solvent evaporation merupakan metode yang paling konvensional dalam pembuatan kokristal. Di dalam teknik ini semua bahan dicampur dengan pelarut dan diuapkan. Selama tahap penguapan larutan molekul diharapkan terjadi berbagai reaksi ikatan hidrogen. Tetapi dalam pembentukan kokristal yang terdiri dari coformer dan bahan aktif, kelarutan keduanya terhadap pelarut yang dipilih memainkan peran besar. Jika kelarutan keduanya tidak sama, maka yang kelarutannya lebih rendah akan mengendap. Molekul harus memiliki kemampuan untuk berinteraksi antar molekul untuk membentuk kokristal (13).

\section{Solvent Drop Grinding}

Teknik solvent drop grinding yang merupakan salah satu metode yang mudah, murah dan bersifat ramah lingkungan (7). solvent drop grinding merupakan modifikasi dari teknik penggilingan padat dimana dengan teknik ini dua bahan dapat digiling dengan menambahkan sejumlah kecil pelarut (15). Kriteria teknik ini adalah pelarut yang ditambahkan dalam jumlah yang sangat kecil yang bila 
ditambahkan bertindak sebagai katalis. Kegunaan solvent-drop grinding pertama kali ditunjukkan dalam konteks peningkatan laju kristalisasi bersama dalam suatu sistem yang melibatkan beberapa kokristal dari basa nitrogen. kokristal dapat dengan mudah dibuat dengan metode grinding, namun solvent-drop grinding dapat digunakan untuk menyiapkan fase kokristal murni dengan waktu yang singkat (13).

\section{Slurry}

Pembuatan kokristal dengan tehnik slurry adalah proses sederhana yang meliputi penambahan pelarut kristalisasi pada bahan aktif farmasi dan koformer yang sesuai. Pemilihan proses ini sangat tergantung pada stabilitas fisik dari senyawa zat aktif yang berbentuk padat yang dilarutkan untuk membentuk larutan. Koformer yang berbentuk padat ditambahkan ke dalam larutan tersebut, kemudian membentuk suspensi dan diaduk sampai pembentukan kokristal selesai. Pada pembuatan kokristal untuk Trimethoprim dan sulfametoksazol melalui teknik bubur digunakan air suling sebagai pelarut. Namun metode ini memiliki kerugian yaitu hasil yang diperoleh tidak mencukupi dibandingkan dengan metode solvent drop grinding (13).

\section{Koformer Nikotinamid}

Nikotinamid telah banyak digunakan sebagai koformer dalam pembentukan ko-kristal dengan ibuprofen (16), simvastatin (14), trimethoprim (10), carvedilol (5), furosemide (17) dan banyak lagi. Adanya gugus amida pada nikotinamid dapat membuka peluang terbentuknya ikatan hidrogen. Nikotinamid adalah bahan yang aman untuk dikonsumsi manusia sehingga memenuhi persyaratan suatu zat yang dapat digunakan sebagai koformer. Berdasarkan struktur kimianya, nikotinamid memiliki peluang besar untuk membentuk ko-kristal dengan berbagai macam bahan aktif farmasi (18).

Nikotinamid banyak digunakan sebagai koformers hidrofilik dalam pembentukan kokristal. Sebagai koformer, nikotinamid memiliki atom nitrogen di kelompok piridin yang dapat membentuk heterosinton dengan bahan aktif farmasi antara asam karboksilat...piridin, amida...piridin, atau interaksi lainnya. Adanya gugus amida juga dapat membentuk atau heterosinton dengan antar amida $\cdots$ amida atau asam karboksilat $\cdots$ amida (11).

Nikotinamid dikenal sebagai bahan penghidrotropi. Istilah hidrotropi dikenal sebagai proses solubilisasi non-stoikiometrik suatu zat terlarut dengan adanya konsentrasi tinggi senyawa aromatik anionik di dalam larutan. Hidrotropi adalah suatu fenomena molekular dimana peningkatan kelarutan di dalam air suatu zat tidak hanya disebabkan penambahan bahan penghidrotropi aromatik anionik, tetapi juga aromatik kationik dan nonionik. Nikotinamid dikenal memiliki kemampuan untuk meningkatkan kelarutan berbagai BAF. Nikotinamid mampu meningkatkan kelarutan berbagai BAF melalui pembentukan stacking complex. Pembentukan stacking complex antara nikotinamid dan BAF umumnya berkaitan dengan interaksi antara donor $\pi$ dan akseptor $\pi$ elektron. Kompleks terbentuk antara bagian datar hidrofobik (aromatik) bahan pengompleks dan BAF. Susunan bertumpuk mirip sandwich melindungi bagian hidrofobik BAF dari air. Pembentukan kompleks dapat meningkatkan kelarutan obat dalam air. Nikotinamid memiliki kelarutan yang tinggi dalam air. Nikotinamid banyak digunakan untuk meningkatkan kelarutan beberapa obat. Pembentukan kompleks dapat memperbaiki stabilitas kimia BAF (18). 


\section{Pembahasan}

Metode-metode modifikasi kokristal menggunakan koformer nikotinamid

Tabel I. Nilai kelarutan modifikasi kokristal menggunkan koformer nikotinamid

\begin{tabular}{|c|c|c|c|}
\hline Zat aktif & Metode & Nilai kelarutan & Ref \\
\hline $\begin{array}{lll}\text { Asam } & \text { mefenamat } \\
\mu \mathrm{g} / \mathrm{mL})\end{array}$ & Melt crystallization & $10.45 \mu \mathrm{g} / \mathrm{mL}$ & (19) \\
\hline $\begin{array}{l}\text { Kalsium atorvastatin }(0,152 \\
\mathrm{mg} / \mathrm{mL})\end{array}$ & Solvent drop grinding & $0,206 \mathrm{mg} / \mathrm{mL}$ & (7) \\
\hline $\begin{array}{l}\text { Simvastatin } \\
(9 \mu \mathrm{g} / \mathrm{mL})\end{array}$ & Solvent evaporation & $30 \mu \mathrm{g} / \mathrm{mL}$ & (14) \\
\hline Diflunisal $(47 \mu \mathrm{g} / \mathrm{mL})$ & Solvent evaporation & $66 \mu \mathrm{g} / \mathrm{mL}$ & (11) \\
\hline $\begin{array}{l}\text { Artesunate } \\
(1,2 \mathrm{mg} / \mathrm{mL})\end{array}$ & $\begin{array}{l}\text { Slurry } \\
\text { Solvent evaporation }\end{array}$ & $\begin{array}{l}1,3 \mathrm{mg} / \mathrm{mL} \\
1,4 \mathrm{mg} / \mathrm{mL}\end{array}$ & (20) \\
\hline $\begin{array}{l}\text { Furosemide } \\
(0.006 \mathrm{mg} / \mathrm{mL})\end{array}$ & Solvent drop grinding & $1000 \mathrm{mg} / \mathrm{mL}$ & (17) \\
\hline $\begin{array}{l}\text { Carvedilol } \\
(0,093 \mathrm{mg} / \mathrm{mL})\end{array}$ & HME & $1,41 \mathrm{mg} / \mathrm{mL}$ & (5) \\
\hline $\begin{array}{l}\text { Prulifloxacin } \\
(20 \mu \mathrm{g} / \mathrm{ml})\end{array}$ & Solvent evaporation & $120 \mu \mathrm{g} / \mathrm{ml}$ & (21) \\
\hline $\begin{array}{l}\text { Didanosin } \\
(26,42 \mathrm{mg} / \mathrm{mL})\end{array}$ & Slurry & $49,13 \mathrm{mg} / \mathrm{mL}$ & (18) \\
\hline
\end{tabular}

\section{Physical Mixtures}

Campuran fisik antara bahan aktif farmasi dan koformer biasanya selalu dilakukan dalam setiap percobaan pembuatan kokristal. Utami dkk melakukan sitesis kokristal asam mefenamat dengan koformer nicotinamid. Dilakukan juga pencampuran fisik antara asam mefenamat dengan nikotinamid sebagai pembanding yang kemudian dilakukan evaluasi terhadap kelarutannya terhadap air, terlihat dari hasil nilai kelarutan jenuh campuran fisik asam mefenamatnicotinamid meningkat dibandingkan dengan asam mefenamat murni. Masing masing nilai kelarutannya $7.35 \mu \mathrm{g} / \mathrm{mL}$ dan $6.62 \mu \mathrm{g} / \mathrm{mL}$ (19). Pada kesempatan lain, lyan S dkk, juga melakukan sintesis kokristal simvastatin dengan koformer nikotinamid dan dibuat campuran fisik sebagai pembanding. Setelah dilakukan uji kelarutan jenuh Hasil kelarutan jenuh co-kristal menunjukkan peningkatan tiga kali lipat dibandingkan dengan simvastatin murni dan campuran fisik (14). Dwi S, dkk juga melkukan percobaan sintesis kokristal dari Artesunate sebagai obat malaria. Dilakukan juga campuran fisik antara Artesunate-nicotinamidserta dilakukan uji kelarutan. Dari uji kelarutan, diketahui bahwa kelarutan Artesunate pada campuran fisik sedikit meningkat (20). Peningkatan kelarutan campuran fisik antara bahan aktif farmasi dengan nikotinamid sebagai koformer karena dipengaruhi oleh sifat kelarutan nikotinamid sehingga bahan aktif farmasi lebih mudah dibasahi oleh pelarut.

\section{Solvent Evaporation}

Penguapan pelarut merupakan teknik yang paling sederhana dalam sintesis kokristal. Teknik ini menggunakan prinsip pelarutan bahan aktif farmasi dan koformer dengan pelarut yang sesuai. Interaksi molekuler diharapkan terjadi pada proses pelarutan kedua senyawa tersebut sehingga terbentuk ikatan hidrogen 
dimana interaksi ini merupakan hal yang diharapkan dalam proses kokristalisasi. Kemudian proses penguapan pelarut bertujuan untuk manghilangkan pelarut hingga terbentuk padatan kristal yang memiliki sifat fisiko kimia yang berbeda dengan zat murninya.

Dalam penelitiannya lyan $S$ dkk melakukan sintesis kokristal simvastatin dengan penambahan nicotinamide sebagai koformer dengan tehnik solvent evaporation untuk memperbaiki sifat fisikokimia simvastatin yang memiliki kelarutan kecil dalam air. Setelah terbentuk kokristal simvastatin-nicotinamid terjadi peningkatan kelarutan 3 kali dari kelarutan simvastatin murni. Kokristal simvastatinnikotinamid menunjukanan nilai kelarutan dalam air sebesar $30 \mu \mathrm{g} / \mathrm{mL}$ (14).

Lianyan W, dkk juga melakukan penelitian sintesis kokristal degan bahan aktif diflunisal dan nikotinamide sebagai koformer dengan teknik solvent evaporation. Kokristal yang terbentuk memiliki kelarutan yang lebih tinggi dari pada diflunisal murni, kelarutan kokristal mencapai $66 \mu \mathrm{g} / \mathrm{mL}$, yaitu 1.5 kali dari diflunisal, diflunisal murni memiliki kelarutan sedang $47 \mu \mathrm{g} / \mathrm{mL}$, Peningkatan kelarutan 1,5 kali lipat juga menawarkan pilihan potensial untuk mengurangi dosis bahan aktif farmasi yang dibutuhkan oleh pasien dan, akibatnya, kemungkinan besar dapat menurunkan biaya pengobatan (11).

Pada sintesis kokristal artesunate dengan nikotinamide sebagai koformer yang dilakukan oleh Dwi. S dkk, nampak perubahan dari kemampuan artesunate larut jenuh dalam air suling pada $37 \pm 0,5^{\circ} \mathrm{C}$. Hasil uji kelarutan jenuh artesunate menunjukkan bahwa terjadi peningkatan kelarutan karena adanya ikatan hidrogen antara artesunate dan nikotinamid. Nikotinamid larut dalam air sehingga ketika artesunate - nikotinamid terikat dalam bentuk kokristal, kelarutan AR juga akan meningkat. Peningkatan kelarutan AR juga dapat dilihat dari penurunan titik leleh yang terjadi pada kokristal. Analisis termal dengan analisis termal diferensial, titik leleh kokristal artesunate-nicotinamid adalah 98,4 ${ }^{\circ} \mathrm{C}$. Berkurangnya titik leleh mengindikasikan berkurangnya energi kisi kristal, sehingga menghasilkan kokristal yang lebih mudah larut (20).

Kelarutan prulifloxacin juga dapat dimodifikasi melalui pembentukan cocrystal. Studi kelarutan jenuh awal dilakukan untuk kokristal prulifloxacin- nikotinamid dengan menggunakan air dalam water bath shaker pada suhu $35 \pm 2^{\circ} \mathrm{C}$. Hasil penelitian menunjukkan bahwa kokristal prulifloxacin-nikotinamid memiliki nilai kelarutan lebih tinggi yaitu $120 \mu \mathrm{g} / \mathrm{ml}$ dari prulifloxacin murni $20 \mu \mathrm{g} / \mathrm{ml}$ dalam air. Ini menunjukkan prulifloxacin murni memiliki memiliki masalah kelarutan. Masalah yang mungkin terjadi dapat diatasi dengan modifikasi kokristal, yang dapat meningkatkan kelarutan. Peningkatan kelarutan 5-6 kali lipat juga menawarkan pilihan potensial untuk mengurangi dosis obat yang dibutuhkan oleh pasien dan dapat menurunkan biaya perawatan (21).

\section{Solvent Drop Grinding}

Solvent drop grinding adalah metode alternatif untuk menghasilkan kokristal. Teknik ini dianggap mudah dan ramah lingkungan yang memungkinkan untuk menghasilkan kokristal dengan penggunaan pelarut yag sedikit, dan bahkan dalam beberapa kasus penggunaan pelarut tidak diperlukan. solvent drop grinding merupakan modifikasi dari teknik penggilingan padat dimana dengan teknik ini dua bahan dapat digiling dengan menambahkan sejumlah kecil pelarut. Kriteria teknik ini adalah pelarut yang ditambahkan dalam jumlah yang sangat kecil yang bila ditambahkan bertindak sebagai katalis (22). Rajesh dkk melakukan sintesis kokristal furosemide dengan nikotinamid sebagai koformer. Sintesis kokristal dilakukan dengan tehnik solvent drop grinding. Dari hasil uji kelarutan terlihat ada peningkatan kelarutan pada kokristal furosemide-nikotinamid dibandingkan dengan furosemide murni dengan nilai kelarutan $1000 \mathrm{mg} / \mathrm{mL}$ dan $0,006 \mathrm{mg} / \mathrm{mL}$ (17). 
Dolih G dkk melakukan penelitian sintesis kokristal kalsium atovarstatin dengan koformer isonikotinamid. Kokristal yang terbentuk dari metode solvent drop grinding antara zat aktif dan koformer masing-masing diuji kelarutannya dan dibandingkan dengan kalsium atorvastatin standarnya. Pengujian ini dilakukan dengan menambahkan sampel yang mengandung $20 \mathrm{mg}$ kalsium atorvastatin ke dalam $10 \mathrm{~mL}$ air dan dikocok dengan agitator mekanik selama 48 jam pada suhu $25^{\circ} \mathrm{C}$ dengan kecepatan $120 \mathrm{rpm}$. Terlihat bahwa kokristal kalsium atorvastatin yang terbentuk memiliki kelarutan yang lebih tinggi bila dibandingkan dengan kalsium atorvastatin standarnya. Kokristal yang dibentuk melalui metode solvent drop grinding memperlihatkan peningkatan kelarutan sebesar $35,52 \%$ dengan nilai kelarutan $0,206 \mathrm{mg} / \mathrm{mL}$. Peningkatan kelarutan tersebut dapat disebabkan oleh beberapa mekanisme diantaranya karena adanya pembentukkan fase kristalin baru kokristal yang memiliki sifat fisikokimia yang lebih baik termasuk kelarutannya. Isonikotinamida dilaporkan dapat membentuk kompleks dengan senyawa obat seperti kalsium atorvastatin melalui mekanisme sebagai donor dan akseptor dalam pembentukan ikatan hidrogen. Hal ini juga menyebabkan adanya peningkatan kelarutan melalui pembentukan kompleks kokristal. (7)

\section{Slurry}

Metode slurry digunakan dengan mencampur bahan aktif farmasi dengan koformer, kemudian ditambahkan pelarut yang tepat dalam suhu kamar sehingga didapat campran seperti bubur. Campuran itu diuapkan sampai semua pelarut hilang dari campuran padat dan dianggap sebagai metode sintesis kokristal yang sederhana.(8)

Pada sintesis kokristal artesunate dengan nikotinamide sebagai koformer, Dwi. $S$ dkk, juga mensintesis kokristal dengan tehnik slurry. Perubahan terlihat dari hasil uji kelarutan jenuh artesunate. Hasil uji menunjukkan bahwa terjadi peningkatan kelarutan kokristal artesunate-nikotinamide dengan tehnik slurry dibandingkan dengan artesunate murni. Namun peningkatan yang terjadi nilai kelarutannya masil lebih kecil dibanding dengan kokristal artesunate-nikotinamide yang dibuat dengan tehnik solvent evaporation. Peningkatan kelarutan ini terjadi juga karena adanya ikatan hidrogen antara artesunate dan nikotinamid, namun pada tehnik slurry pelarut yang digunakan sedikit sehingga reaksi yang terjadi antara bahan aktif farmasi dan koformer tidak maksimal. Jika dibandingkan dengan metode solvent evaporation proses melarutnya kedua komponen yaitu bahan aktif farmasi dan koformer merupakan saat terjadinya interaksi diantara kedua komponen tersebut.(20)

Pada penelitian fikri alatas, dkk, Hasil pengujian kelarutan kokristal DDI-NKT menunjukkan hasil 1,86 kali lipat dari kelarutan DDImurni. Kelarutan DDI dan kokriatal DDI-NKT berturut-turut adalah $26,42 \pm 0,41 \mathrm{mg} / \mathrm{mL}$ dan 49,13 $\pm 0,36$ $\mathrm{mg} / \mathrm{mL}$.

\section{Hot Melt Extrusion}

Gasper dkk, melakukan penelitian tentang sintesis kokristal carvedilolnicotinamide yang diproduksi melalui HME menunjukkan hasil kelarutan yang lebih tinggi dibanding zat murninya, dengan itu HME menunjukkan teknik yang baik untuk meningkatkan kelarutan. Ekstrusi juga merupakan metode yang berguna untuk sintesis kokristal, pencampuran yang terjadi sangat efisien dan kontak permukaan antar zat lebih baik, pembentukan kokristal tanpa menggunakan pelarut. Pemilihan Metode ini terutama tergantung pada stabilitas termodinamika senyawa. Teknik HME biasanya digunakan pada zat yang tahan terhadap pemanasan. Sehingga tidak terjadi kerusakan senyawa obat yang disebabkan oleh suhu tinggi pada proses produksi. Pada kokristal carvedilol nilai kelarutan terhadap 
larutan $0.1 \mathrm{~N} \mathrm{HCl}$ pada $\mathrm{pH} 1.2$ dan suhu $37^{\circ} \mathrm{C}$ adalah $1.41 \mathrm{mg} / \mathrm{ml}$ sedangkan kelarutan carvedilol murni adalah $0.093 \mathrm{mg} / \mathrm{ml}$.

\section{Disolusi Kokristal}

Disolusi merupakan suatu proses dimana obat menjadi terlarut dalam suatu pelarut dalam waktu tertentu. Disolusi juga menjadi parameter dalam melihat perubahan sifat fisikokimia suatu bahan aktif farmasi yang di sertakan dengan data kelarutan. Modifikasi kokristal bahan aktif farmasi juga dapat maningkatkan laju disolusi dari bahan aktif farmasi itu sendiri dibandingkan kecepatan disolusi bahan aktif farmasi murninya. Kokristal DIF-NIC menunjukkan laju disolusi lebih cepat daripada DIF murni(11), terlihat peningkatan laju disolusi kokristal furosemide-nic dalam $10 \% \mathrm{EtOH}-$ Water $111 \times 10-3\left(\mathrm{mg} / \mathrm{cm}^{2}\right) / \mathrm{min}$ dibandingkan dengan furosemide murni dengan nilai $44 \times 10-3\left(\mathrm{mg} / \mathrm{cm}^{2}\right) / \mathrm{min}(17)$

Hasil uji disolusi AR, CoAR-NIC dengan tehnik Slurry dan CoAR-NIC dengan tehnik Solvent Evaporation dapat dilihat bahwa co-kristal AR - nicotinamide yang disiapkan oleh kedua teknik ini memiliki laju disolusi yang lebih tinggi daripada AR murni. CoAR-NIC dengan tehnik Solven Evaporation memberikan nilai disolusi tercepat. Dari efisiensi disolusi (ED30), diketahui bahwa disolusi dari CoAR-NIC dengan tehnik Solven Evaporation dan CoAR-NIC dengan tehnik Slurry meningkat dibandingkan dengan AR murni. Laju disolusi meningkat karena meningkatnya kelarutan AR (20).

Pada penelitan Gasper dkk, Carvedilol murni menunjukkan profil disolusi maksimum $18,35 \%$ dalam 60 menit. Persentase pelepasan obat pada akhir 60 menit untuk kokristal carvedilol-nikotinamid adalah $88 \%$ dalam 60 menit. Peningkatan pelepasan obat mungkin karena pembentukan ikatan hidrogen antara kelompok fungsional amida dan kelompok karboksil nikotinamid. Karena nikotinamid dalam kaitannya dengan carvedilol, ia meningkatkan polaritas hidrokarboksil hidroksil sehingga meningkatkan kelarutannya (5) dan Nilai disolusi dari co-kristal SV-Nic menunjukkan peningkatan sekitar empat kali dibandingkan dengan nilai SV murni selama periode 60 menit (14).

Menurut zaini dkk, Trimetoprim memiliki kelarutan dan laju disolusi yang rendah dalam air. Dapat dilaukan modifikasi dengan teknik ko-kristalisasi menggunakan nikotinamida sebagai koformer dapat meningkatkan laju disolusi dalam medium air dibandingkan dengan trimetoprim tunggal. Peningkatan kelarutan dan laju disolusi trimetoprim disebabkan berbagai mekanisme, diantaranya pembentukan eutektik antara nikotinamida dan trimetoprim yang memperkecil ukuran partikel trimetoprim. Efek solubilisasi dari nikotinamida yang mudah larut air juga ikut berkontribusi terhadap peningkatan laju disolusi trimetoprim, karena trimetoprim terdispersi dalam nikotinamida.(10)

Dilakukan juga penelitin untuk memperbaiki sifat fisikokimia dari Naproxen terlihat adanya peningkatan laju disolusi untuk co-kristal Naproxen-Nic adalah 51,0 $\mu \mathrm{g}$ min $/ \mathrm{cm}^{2}$. Nilai ini 7,08 kali lebih tinggi dari itu untuk NAP $7,2 \mu \mathrm{g} \min / \mathrm{cm}^{2}$. Demikian pula dalam buffer fosfat $\mathrm{pH} 7,4$ untuk co-kristal $1520 \mu \mathrm{g} \mathrm{min} / \mathrm{cm}^{2}$. Nilai ini 2,75 kali lebih tinggi dari itu untuk NAP $552 \mu \mathrm{g} \mathrm{min} / \mathrm{cm}^{2}$. Nikotinamid menjadi koformer hidrofilik yang mungkin menjadi penyebab untuk meningkatkan pembasahan partikel obat hidrofobik dengan media disolusi dan memberikan efek positif pada profil disolusinya (23).

\section{Kesimpulan}


Kokristal dapat dijadikan suatu tehnik modifikasi untuk memperbaiki sifat sisikokimia bahan aktif farmasi yang memiliki kelarutan yang rendah. Kokristal dapat terbentuk antara suatu bahan aktif farmasi dengan koformer yang memiliki ikatan hidrogen dengan bahan aktif farmasi tersebut untuk membentuk sebuah kristal baru. Bahan aktif farmasi yang dapat membentuk ikatan hydrogen memiliki gugus $\mathrm{OH}$, sedangkan nikotinamida yang berfungsi sebagai koformer memiliki gugus amida sehingga memungkinkan terjadinya ikatan hidrogen antara bahan aktif farmasi dengan nikotinamida melalui suatu metode pembentukan kokristal sehingga terbentuk kokristal BAF-nikotinamida yang diharapkan dapat meningkatkan sifat-sifat fisikokimia katekin, terutama kelarutannya.

Nikotinamid memiliki sifat hidrotropik, dengan memiliki cincin piridin hidrofobik dan gugus amida hidrophillik. Beberapa hidrotrop agregat secara bertahap proses agregasi diri, meningkatkan ukuran agregasi dan dengan demikian melarutkan senyawa hidrofobik. Tehnik pembentukan juga dapat mempengaruhi efisiensi terbentuknya kokristal dari BAF dan koformer. Pada penggunaan nikotinamid sebagai koformer tehnik solvent evaporator sepertinya menjadi tehnik yang paling sederhana dan efisien dalam pembentukan kokristal BAF-Nikotinamid. Namun untuk keberhasilan modifikasi BAF dalam bentuk kokristalikasi harus memperhatikan sifat sifat BAF yang akan dimodifikasi agar dapat disesuaikan untuk memilih bahan yang akan dijadikan koformer dan tehnik yang akan dipilih dalam pembuatan kokristal.

\section{Daftar Pustaka}

1. Blagden N, de Matas M, Gavan PT, York P. Crystal engineering of active pharmaceutical ingredients to improve solubility and dissolution rates. Adv Drug Deliv Rev. 2007;59(7):617-30.

2. Berry DJ, Steed JW. Pharmaceutical cocrystals, salts and multicomponent systems; intermolecular interactions and property based design. Adv Drug Deliv Rev. 2017;117:3-24.

3. Korotkova El, Kratochvíl B. Pharmaceutical cocrystals. Procedia Chem. 2014;10:473-6.

4. Bakhtiar A, Gaesari SR, Zaini E. Pembentukan kokristal katekin dengan nikotinamida. J Farm Sains dan Terap. 2015;2(2).

5. Fernandes GJ, Rathnanand M, Kulkarni V. Mechanochemical Synthesis of Carvedilol Cocrystals Utilizing Hot Melt Extrusion Technology. J Pharm Innov. 2018;1-9.

6. Sopyan I, Fudholi A, Muchtaridi M, Sari IP. Co-crystallization: A Tool to Enhance Solubility and Dissolution Rate of Simvastatin. J Young Pharm. 2017;9(2).

7. Gozali D, Bahti HH, Soewandhi SN. Pembentukan Kokristal antara kalsium Atovarstatin dengan Isonikotinamid dan Karakterisasinya. Indones J Mater Sci. 2012;15(2):103-10.

8. Kharisma RM, Sopyan I. Dissolution Rate Repairing of Simvastatin as A New Approach in Cocrystallization. Der Pharm Lett. 2017;9(6):18-27.

9. Tomaszewska I, Karki S, Shur J, Price R, Fotaki N. Pharmaceutical characterisation and evaluation of cocrystals: importance of in vitro dissolution conditions and type of coformer. Int J Pharm. 2013;453(2):380-8.

10. Zaini E, Halim A, Soewandhi SN, Setyawan D, Farmasetika D, Farmasi F, et al. Peningkatan Laju Pelarutan Trimetoprim Melalui Metode Ko-Kristalisasi Dengan. J Farm Indones. 2011;5(4):205-12.

11. Wang L, Tan B, Zhang H, Deng Z. Pharmaceutical cocrystals of diflunisal with nicotinamide or isonicotinamide. Org Process Res Dev. 2013;17(11):1413-8. 
12. Raghuram M, Sarwar Alam M, Prasad M, Has Khanduri C. Pharmaceutical cocrystal of prulifloxacin with nicotinamide. Int J Pharm Pharm Sci. 2014;6(10):180-4.

13. Kotak U, Prajapati V, Solanki H, Jani G, Jha P. Co-crystallization technique its rationale and recent progress. World J Pharm Pharm Sci. 2015;4(4):1484-508.

14. Sopyan I, Fudholi A, Muchtaridi M, Puspita Sari I. Simvastatin-nicotinamide cocrystal : design , preparation and preliminary characterization. Trop J Pharm Res. 2017;16(2):297-303.

15. Sopyan I, Fudholi A, Muchtaridi M, Puspitasari I. A Novel of Cocrystalization to Improve Solubility and Dissolution rate of Simvastatin. Int J PharmTech Res. 2016;9(6):483-91.

16. Yuliandra Y, Zaini E, Syofyan S, Pratiwi W, Putri L, Pratiwi Y, et al. Cocrystal of Ibuprofen-Nicotinamide: Solid-State Characterization and In Vivo Analgesic Activity Evaluation. Sci Pharm. 2018;86(2):23.

17. Gangavaram S, Suresh K, Pal S, Manjunatha SG, Nambiar S, Nangia A. Novel Furosemide Cocrystals and Selection of High Solubility. J Pharm Sci. 2012;101(2):664-80.

18. Alatas F, Soewandhi SN, Sasongko L, Ismunandar I. Kelarutan dan Stabilitas Kimia Kompleks Didanosin dengan Nikotinamid atau L-Arginin. Jusami| Indones J Mater Sci. 2018;15(2):94-102.

19. Utami D, Nugrahani I, Ibrahim S. Mefenamic acid-nicotinamide co-crystal synthesized by using melt crystallization method and its solubility study. Asian $\mathrm{J}$ Pharm Clin Res. 2017;10(5):135-9.

20. Setyawan D, Wardhana NK, Sari R. Solubility, dissolution test and antimalarial activity of artesunate nicotinamide co-crystal prepared by solvent evaporation and slurry methods. Asian J Pharm Clin Res. 2015;8(2):164-6.

21. Raghuram M, Alam MS, Prasad M, Khanduri CHAS. Innovare Academic Sciences PHARMACEUTICAL COCRYSTAL OF PRULIFLOXACIN WITH NICOTINAMIDE. 2014;6(10):1-5.

22. Hernández-paredes J, Carrillo-pesqueira FJ, Esparza-ponce HE, Hernándeznegrete $\mathrm{O}$, Alvarez-ramos ME. L -Proline - sodium nitrate obtained from solvent drop grinding. Polyhedron. 2015;91:84-8.

23. Abbas N, Latif S, Afzal H, Arshad MS, Hussain A, Sadeeqa S, et al. Simultaneously Improving Mechanical, Formulation, and In Vivo Performance of Naproxen by Co-Crystallization. AAPS PharmSciTech. 2018;19(7):3249-57. 